\title{
16. PROBLEMS ASSOCIATED WITH THE INTERPRETATION OF NORMAL FAULT DISTRIBUTIONS IN SEDIMENTS RECOVERED BY THE ADVANCED HYDRAULIC PISTON CORER DURING LEG 160, EASTERN MEDITERRANEAN ${ }^{1}$
}

\author{
Achim Kopf ${ }^{2}$ and Rachel Flecker ${ }^{3}$
}

\begin{abstract}
An extensive structural database collected during ODP Leg 160 (Eastern Mediterranean) provides the basis for a study of normal fault distributions. Numerous moderate to steep normal faults were observed crosscutting cores recovered using the advanced hydraulic piston corer (APC) technique. There is an apparent systematic, bimodal distribution of the poles to these faults with respect to the core liner at eight of the sites drilled (963-970). As the core barrel penetrates sediment without systematic orientation relative to geographic north, faults measured with respect to the core liner are expected to have a random distribution. The bimodal distribution observed can be explained by measurement bias resulting from the small apparent dip angles of faults on the cut core face. A significant number of fault planes is therefore likely to be missing from the database. Reorientation of fault planes to geographic coordinates utilized Tensor orientation tool data. This was shown to be unreliable in comparison with paleomagnetic information on one occasion. For this reason, care must be taken when interpreting reoriented fault data with respect to their tectonic setting. Furthermore, tectonic faults are not easily distinguished from brittle failure induced by the APC technique. The normal fault population collected on Leg 160 may therefore contain structures generated as a consequence of APC drilling.
\end{abstract}

\section{INTRODUCTION}

Evidence from many Ocean Drilling Program (ODP) legs shows that normal faulting is a common phenomenon in unconsolidated sediment cores, which are usually recovered using the advanced hydraulic piston corer (APC; cf., Nierenberg and Peterson, 1984). Numerous high-angle normal faults crosscutting cores were identified in layered deep-sea sediments recovered during drilling in the Eastern Mediterranean (ODP Leg 160), and these provide the primary database for this study. Structural measurements were collected from different tectonic and sedimentological environments (see "Geological Setting" section, chapters for Sites 963-970, this volume).

Three-dimensional fault data were obtained from APC cores recovered during Leg 160 by measuring two apparent dips (Fig. 1A), or one apparent dip and the strike of the fault (Fig. 1B) and calculating the common plane (cf., "Structural Geology" section, "Explanatory Notes" chapter, this volume). Plotting these planes as poles to faults resulted in apparent bimodal fault distributions with respect to the core liner. The faults were reoriented to geographic coordinates using Tensor orientation tool data on Leg 160. Previous ODP legs also used reorientation data from paleomagnetic measurements and the Multishot tool to perform this correction (e.g., "Structural Geology" section, "Explanatory Notes" chapter, ODP Leg 141 Initial Reports; Behrmann, Lewis, Musgrave, et al., 1992). The reliability of these reorientation tools has been questioned previously (e.g., Taira, Hill, Firth, et al., 1991; MacLeod et al., 1994). Problems concerning the distinction between tectonic faults and drilling-induced brittle deformation must also be considered. The criteria by which tectonic faults are identified as well as the difficulties in interpreting the uncorrected and reoriented distributions are discussed below.

'Emeis, K.-C., Robertson, A.H.F., Richter, C., et al., 1996. Proc. ODP, Init. Repts., 160: College Station, TX (Ocean Drilling Program).

${ }^{2}$ Institut für Geowissenschaften und Lithosphärenforschung, Universitắt Giessen, Senckenbergstrasse 3, 35390 Giessen, Germany. achim.kopf@geo.uni-giessen.de

${ }^{3}$ Department of Geology and Geophysics, Edinburgh University, West Mains Road, Edinburgh EH9 3JW, United Kingdom.

\section{DATA}

\section{Fault Type}

Moderate to steep $\left(55^{\circ}-80^{\circ}\right.$; cf., Fig. 2$)$ normal faults dominate the APC cores at the majority of sites drilled during Leg 160. For brevity, the description of fault style, distribution, and tectonic setting is kept to a minimum. For more detailed information the reader is referred to the individual site chapters (see "Structural Geology" section, chapters for Sites 963-970, this volume).

Different styles of normal faulting were observed. Single, steep normal faults crosscutting the core face are the most common type of occurrence, although sets of en echelon faults (e.g., Section 160967B-5H-3) and of normal faults with variable dip (e.g., Section 160$968 \mathrm{~A}-4 \mathrm{H}-5$, and Fig. 25 in the "Site 968 " chapter, this volume) were also observed. Planar and curviplanar to irregular fault planes were found, some of which were diagenetically altered (e.g., evidence of fluid mobility). Dips vary from shallow to steep (some are vertical), but are dominantly moderate to $\operatorname{steep}\left(55^{\circ}-80^{\circ}\right.$; Fig. 2$)$. The displacement of bedding planes and geochemical fronts along faults ranges from a few millimeters to more than $20 \mathrm{~cm}$. Indications of geochemical mobility, for example, uninterrrupted redox fronts across fault surfaces and evidence of fluid migration along them, were rarely observed.

\section{Fault Distribution}

All faults with obvious normal displacements in the APC cores collected during Leg 160 that could be measured in three dimensions with respect to the core liner are shown in Figure 3. The data set consists of 135 fault planes. These faults are plotted as poles to planes and show an apparent broad bimodal distribution (Fig. 3) in which the majority of faults have dip directions between $35^{\circ}$ and $145^{\circ}$ and between $215^{\circ}$ and $325^{\circ}$ (Fig. 2B). This distribution is unexpected, given the random orientation of the core liner as it enters the sediment with respect to geographic coordinates (Table 1, Fig. 4) from which a scattered pole figure would be predicted.

Reorientation of faults to geographic coordinates produced variable distributions ranging from patterns of fault poles that it was pos- 

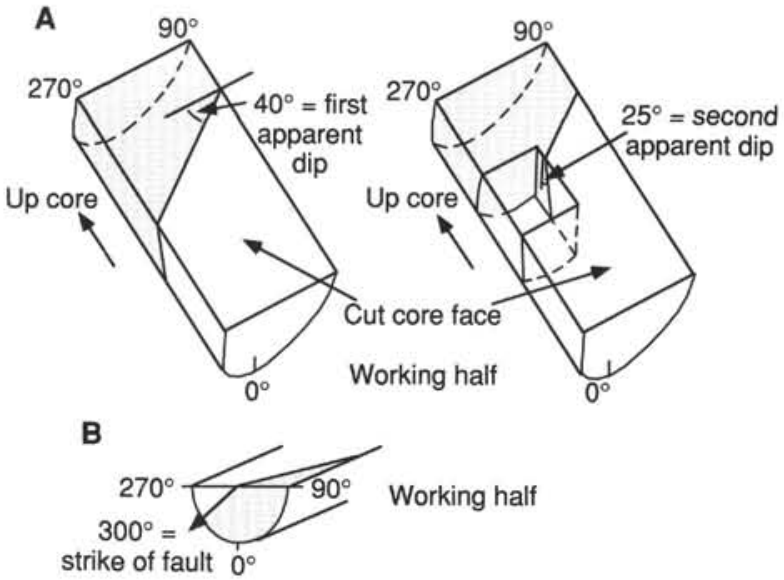

Figure 1. Diagram showing the conventions used in measuring (A) two apparent dips with respect to the core reference frame on the core face $(90 \%$ $270^{\circ}$ section) and on the $180^{\circ} / 360^{\circ}$ section and (B) the azimuth of the fault on the plane perpendicular to the core axis $\left(0^{\circ}\right.$-dip section).

sible to relate to the geological setting (e.g., Fig. 26, "Structural Geology" section, "Site 964 " chapter, this volume) to ones in which this relationship is less obvious (e.g., Fig. 33B, "Structural Geology" section, "Site 967 " chapter, this volume). The Tensor tool reorientation values were shown to be inaccurate at one site where it was possible to check them against paleomagnetic data (e.g., "Structural Geology" section, "Site 966" chapter, this volume). For the other sites where the reorientation data could not be validated, fault distributions with respect to geographic north and their relation to the tectonic setting remain in doubt.

Reoriented pole figures in which Tensor tool data were used and the uncorrected fault distributions are shown in the "Structural Geology" section in the site chapters (Fig. 22 in the "Site 963" chapter, Fig. 26 in the "Site 964" chapter, Fig. 19 in the "Site 965" chapter, Fig. 33 in the "Site 966" chapter, Fig. 33 in the "Site 967" chapter, Fig. 27 in the "Site 968" chapter, and Fig. 34 in the "Site 969" chapter, this volume).

\section{Fault Frequency}

Normal faults were found in APC cores at all sites drilled during Leg 160 independent of tectonic setting, and they appear to be more abundant in well-layered intervals than in homogeneous sediment (see Table 6 in the "Site 963" chapter, Table 5 in the "Site 964" chapter, Table 4 in the "Site 965 " chapter, Table 5 in the "Site 966" chapter, Table 4 in the "Site 967" chapter, Table 4 in the "Site 968" chapter, Table 5 in the "Site 969 " chapter, Table 4 in the "Site 970 " chapter, and core photographs in Section 5, this volume). A decrease in frequency of normal faulting was also observed over intervals without marked changes in physical and lithologic properties. At both Holes 966D and 968A, this reduction is coincident with a change from APC to extended core barrel (XCB) coring (Table 6 in the "Site 963 " chapter and Table 4 in the "Site 968 " chapter, this volume).

\section{DISCUSSION}

The discussion of problems arising from the distribution of normal faults collected on Leg 160 focuses on three aspects: (1) measurement bias is considered as a possible explanation for the apparent bimodal distribution observed; (2) corrected fault distributions are
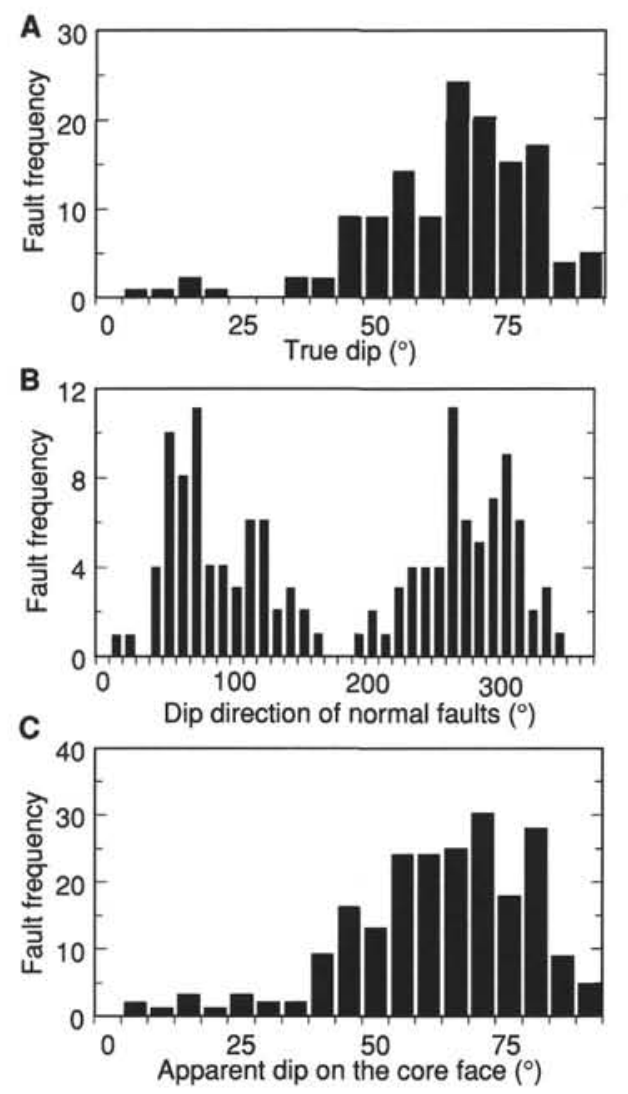

Figure 2. Frequency plots of (A) true dip, (B) dip direction, and (C) apparent dip of all normal faults from sites drilled during Leg 160 .

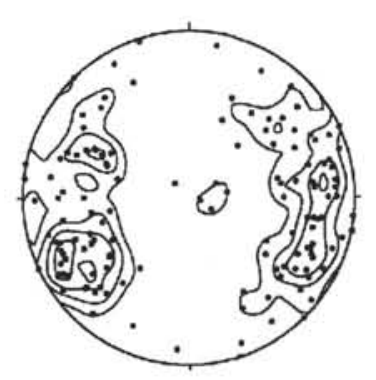

Figure 3. Lower hemisphere equal-area projection of poles to normal faults from Sites 963 through 970 . The data are plotted with respect to the core reference frame.

discussed with respect to the tectonic setting and the possible unreliability of reorientation tools used on previous ODP legs; and (3) a partially nontectonic (i.e., drilling induced) origin for the normal fault population is also considered.

\section{Measurement Bias}

A measurement bias, which results from the exclusion of most or all fault planes dipping toward $360^{\circ}$ and $180^{\circ}$ (in core coordinates; cf., Fig. 1), could explain the apparent bimodal normal fault distribution observed (Fig. 3). Faults intersecting the core face with a low angle of dip in horizontally bedded or homogeneous sediments do not reveal obvious displacements. These fault planes, which, as a result of observational problems are difficult or impossible to measure, fall 
Table 1. Tensor orientation tool log for the Leg 160 holes in this study.

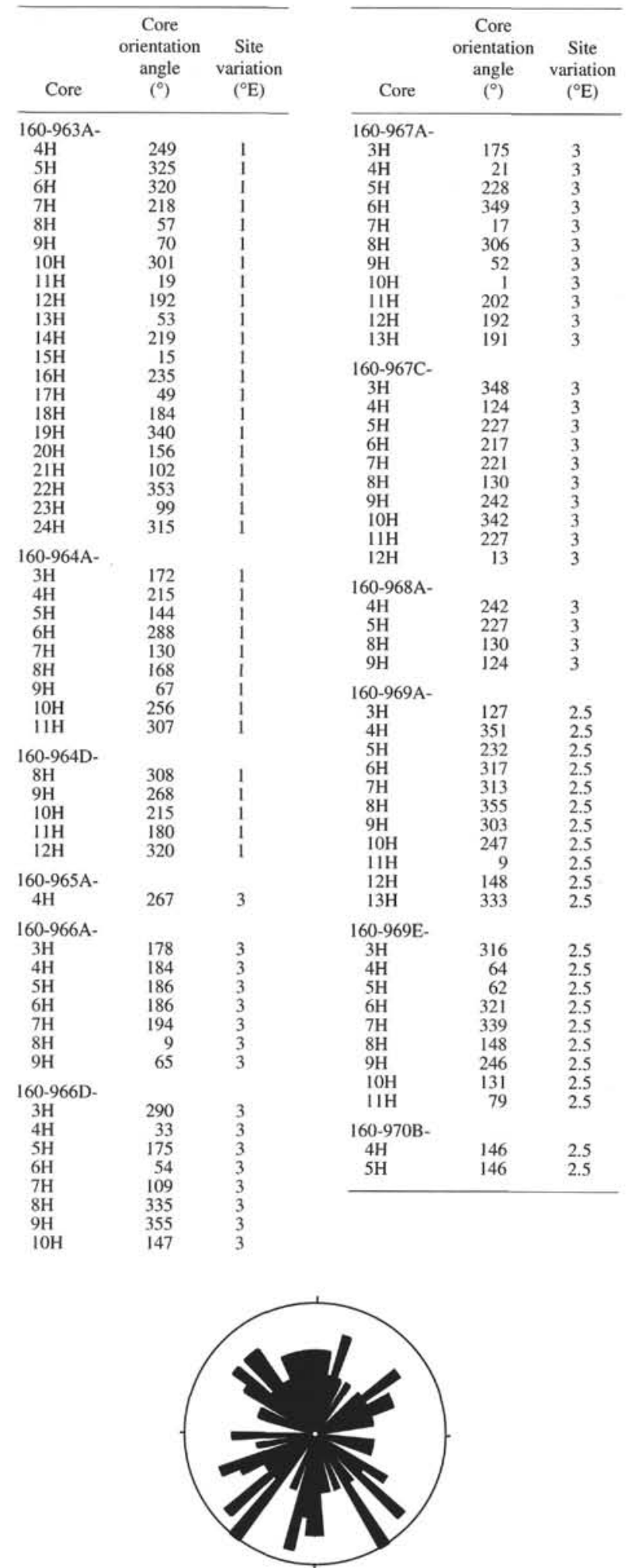

Figure 4. Rose diagram of core reorientation angles determined using the Tensor orientation tool during Leg 160 . The random pattern indicates that the core liner was not systematically oriented with respect to geographic north (see Table 1 for data). into five categories in terms of their orientation with respect to core coordinates:

1. If a low-angle dip on the core face $\left(90^{\circ} / 270^{\circ}\right.$ in core coordinates; Fig. 1A) is the true dip of the fault and it is not observed, then obviously no measurement of the second apparent dip or strike can be made.

2. If a low-angle dip on the core face is an apparent dip on a lowangle fault, then the fault could have any dip direction except due $90^{\circ}$ and due $270^{\circ}$.

3. If a low-angle dip on the core face is an apparent dip on a highangle fault, then this indicates that the fault strike is not far from being parallel to the orientation of the core face $(90 \%$ $270^{\circ}$ section; Fig. 1A). Such faults most likely dip toward $360^{\circ}$ and $180^{\circ}$ in the core coordinate system.

4. If the fault is dipping precisely $180^{\circ}$ or $360^{\circ}$ (core coordinates), its apparent dip on the core face is the strike section and therefore horizontal, independent of the angle of true dip.

5. Even where a fault is observed on the core face $\left(90^{\circ} / 270^{\circ} \mathrm{sec}-\right.$ tion, Fig. 1A), if it cannot be identified on the $0^{\circ}$-dip section (i.e., perpendicular to the core axis; Fig. 1B) it contributes to the measurement bias. The removal of soft sediment from the core liner to create the $0^{\circ}$-dip section often obscures the trace of the fault strikes close to $90^{\circ}$ and $270^{\circ}$ (Fig. 1B). In these cases, a fault observed on the core face may fail to reveal its azimuth so that no three-dimensional orientation can be calculated using this second apparent dip.

Categories 2-5 can explain the pole-free areas in the northern and southern areas of the lower hemisphere plots with respect to core coordinates (Figs. 1, 2).

An assessment of the extent to which measurement bias might be the cause of the fault distribution observed can also be predicted on theoretical grounds. The likelihood of a fault being recognizable on the core face (i.e., its dip angle) is dependent on the degree of lithologic variation in the core and is a function of the sine of the angle between the strike of the fault and the $90^{\circ} / 270^{\circ}$ section of the cut core face (cf., Fig. 5A). Given that a randomly oriented set of faults is drilled, fewer high-angle features are expected to intersect the core face than low-angle ones (directly proportional to the sine of the apparent dip; Fig. 5B). Despite the low gradient of the sine curve toward high apparent dip angles, low-angle features are overrepresented as a result of true dip variation. A comparison between this theoretically expected variety of fault dip angles and those actually recovered on Leg 160 (Fig. 2) and on previous ODP legs (e.g., Leg 141-Behrmann, Lewis, Musgrave, et al., 1992; Leg 159-Mascle, Lohmann, Clift, et al., in press) suggests that a significant amount of low-angle fault data is missing.

Measurement bias can have a profound effect on the distributions of reoriented fault populations if they are derived from a limited number of soft-sediment cores or the Tensor tool correction data for all cores have similar values. Where variable Tensor tool reorientation values are obtained, however, the fault distribution with respect to geographic coordinates does not depend on the number of cores from which these data were collected. In other words, under these circumstances an apparent bimodal distribution with respect to the core liner will not obscure the geographic fault distribution when reoriented. For example, the normal fault data collected at Sites 967, 968, and 969 during Leg 160 have an apparent bimodal distribution with respect to the core liner (cf., "Structural Geology" section, chapters for Sites 967-969, this volume). Correction of these data to geographic coordinates results in a significant redistribution (cf., Table 4 and Fig. 33 in the "Site 967 " chapter, Table 4 and Fig. 27 in the "Site 968 " chapter, and Table 5 and Fig. 34 in the "Site 969" chapter, this volume). The fault data collected during Leg 159 (eastern equatorial Atlantic; Mascle, Lohmann, Clift, et al., in press) behave in a similar manner (E.A. Pickett, pers. comm., 1995; cf., Fig. 6B). 
Nevertheless, measurement bias is a significant problem in terms of reoriented distributions if the data for the cores are limited to correction values within a few degrees each other. In this situation, the distribution with respect to the core liner, though rotated, is likely to remain similar. On Leg 141 (Chile Margin Triple Junction; Behrmann, Lewis, Musgrave, et al., 1992), fault data from APC cores show a bimodal fault distribution, both with respect to core and geographic coordinates (Fig. 6A). These data were derived from only two cores, for which similar Multishot tool data were obtained (i.e., reorientation angles of $37^{\circ}$ and $61^{\circ}$ ). Therefore, although the preferred orientation of corrected fault planes may reflect the tectonic fault distribution, it may also result from making a similar correction to a fault population that already has a bimodal distribution with respect to core coordinates.

\section{Reorientation Tools}

In the above discussion it is assumed that the reorientation data (i.e., Multishot and Tensor tools) used are correct. However, these tools have been found to be inaccurate on several occasions when checked against single paleomagnetic measurements.

Malfunction (attachment of a magnetic collar) of the Tensor tool at Site 966 led to a mismatch between the reorientation values and the results of paleomagnetic measurements (Table 1; e.g., "Paleomagnetism" section, "Site 966" chapter, this volume). Correction of faults from this site to geographic coordinates was therefore impossible. However, for all the other sites the accuracy of the Tensor tool data could not be checked on board. There are therefore two principal interpretations of the reoriented fault distributions: either the reorientation values are correct and there is no preferred orientation to the fault population or the Tensor tool data and resulting reoriented distributions are incorrect. On Leg 131 the Multishot tool was found to be highly unreliable, and the paleomagnetic approach was routinely employed on cores recovered using the APC, XCB, and rotary core barrel (RCB) techniques (cf., Taira, Hill, Firth, et al., 1991). Fault data reoriented to geographic coordinates using this method resulted in a preferred orientation that is related to the tectonic setting (Fig. 7A, B). Similar problems (e.g., unreliability of the Multishot tool, compass misalignment) arose during Leg 135 (Lau Basin; Parson, Hawkins, Allan, et al., 1992) such that paleomagnetic measurements on single samples and core-log integration were favored as methods for core reorientation (MacLeod et al., 1994). Observations collected from several legs therefore suggest that reorientation tool data and the resulting fault distributions should be treated with caution. This is also applicable to the Leg 160 geographic fault distributions until confirmation of the reorientation values is provided by paleomagnetic data.

\section{Drilling-induced Normal Faulting}

A third relevant point in considering fault distributions concerns the cause of brittle failure in soft sediments. Where faults crosscut the entire core with a visible offset they have generally been considered tectonic (e.g., "Structural Geology" section, "Explanatory Notes" chapter, this volume). However, most of these faults show no evidence of geochemical mobilization across the planes or fluid migration along their surfaces. Such observations could be interpreted to indicate a recent age of faulting, consistent with a drilling-induced origin of these features.

In addition, an apparent coincidence between a reduction in frequency of normal faulting and a change from the $\mathrm{APC}$ to the $\mathrm{XCB}$ technique within the same lithostratigraphic unit is found at both Holes 966D and 968A (see above). A similar phenomenon was observed during Leg 110 in Hole 671B (Barbados; Mascle, Moore, et al., 1988). Here, the normal faults are entirely restricted to APC cores and a transition to reverse faulting corresponds to the change in drilling technique (XCB) over an interval that has relatively constant lithologic and physical properties.
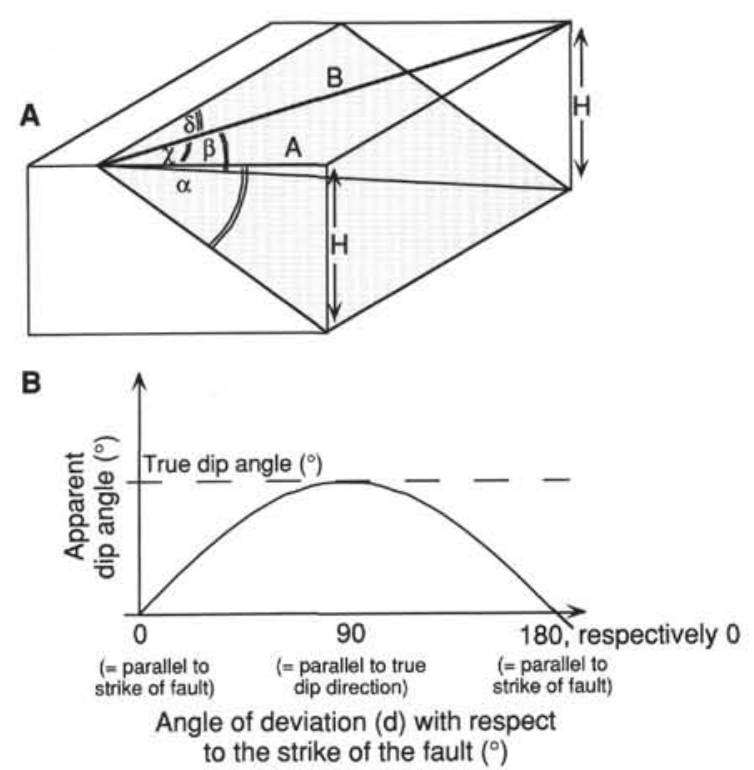

Figure 5. A. Block diagram of a fault surface with true dip $(\alpha)$ and apparent $\operatorname{dip}(\beta)$. From $\tan \alpha=H / A$, and $\tan \beta=H / B$, the angle between $A$ and $B$ on a horizontal reference surface is derived as $\cos \chi=A / B$. The angle of derivation $(\delta)$ between the strike of the fault and the apparent dip on the reference surface is therefore $\delta=90^{\circ}-\chi$. The angle $\delta$ is therefore defined by a sine function, whereas $\chi$ is defined by a cosine function. B. Sine function of the theoretically expected frequency distribution of apparent dip angles on the core face as a function of their deviation from the strike of the fault. The maximum on the $y$ axis is limited by the true dip angle of the fault. As the result of the gradient of the curve, apparent dip angles close to the true dip of the fault are less numerous than predicted.
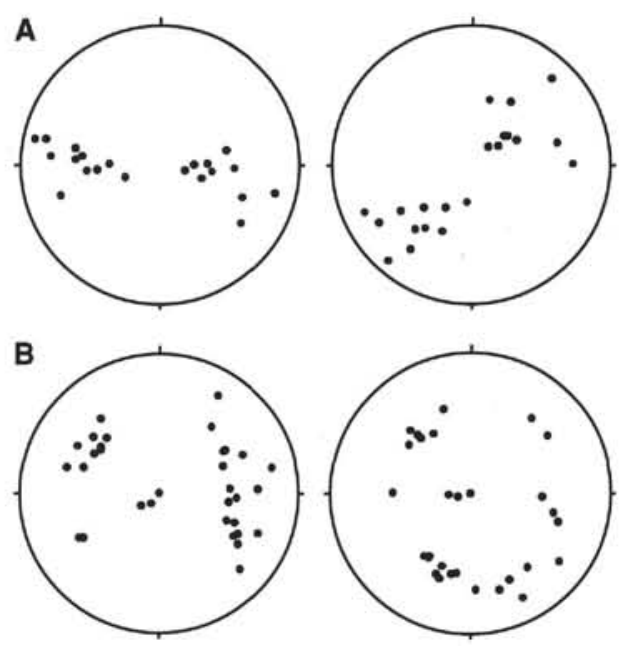

Figure 6. Stereographic projection of poles to normal faults observed in APC cores from (A) Hole 863A and (B) Holes 959A, 960C, and 962B, all of which are reported with respect to both the core reference frame and geographic orientations. See text for discussion.

APC drilling generally requires the application of 16-24 MPa to penetrate $9.5 \mathrm{~m}$ of sediment (Nierenberg and Peterson, 1984). In theory, forces of this order of magnitude are sufficient to cause brittle failure in unconsolidated sediments ahead of the drill bit assembly (Paterson, 1978). Although brittle failure could be generated by the APC technique, the radial fault distribution (core coordinates) expected from the symmetrical drilling device does not resemble the apparent bimodal pole figure (E. Pollard, pers. comm., 1995). Given a 
A
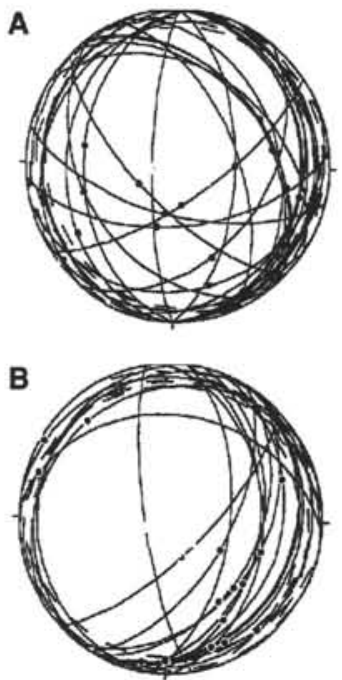

Figure 7. Stereographic projection of poles to normal faults measured in RCB Core 131-808C-29R from Leg 131 (Nankai accretionary wedge) plotted (A) with respect to core coordinates and (B) corrected to geographic coordinates (after Taira, Hill, Firth, et al., 1991).

measurement bias, however, an apparent bimodal distribution will still be found even if the entire fault population is drilling induced. On the basis of distribution alone, it is therefore impossible to determine whether or not a fault population contains drilling-induced features. Furthermore, APC-generated faults cannot have a preferred orientation with respect to geographic coordinates. Therefore, if they dominate a fault population, a reoriented tectonic fault distribution may be masked.

\section{CONCLUSIONS}

An apparently bimodal distribution of poles to normal faults with respect to the core liner was found consistently at Sites 963-970 drilled during Leg 160. A similar distribution is seen in APC cores from several previous ODP legs. Measurement bias that excludes faults dipping northward and southward (core coordinates) may explain the pole distributions and suggests that a significant amount of low-angle fault data is missing. If the same apparent bimodal distribution is obtained from cores split along different sections (e.g., not exclusively along the $90^{\circ} / 270^{\circ}$ section), then this demonstrates unequivocally that measurement bias is entirely responsible for the distribution.
Tensor tool values have been found inaccurate, both at one site during Leg 160 and on several previous ODP legs, such that reoriented data using these values are questionable. Core-log integration and/ or measurement of single paleomagnetic samples has formerly been used to check for, and overcome, these errors. Uncertainty would be avoided if these methods of obtaining information concerning the geographic orientation of cores were used routinely.

Faults crosscutting the core face have been previously assumed to be tectonic, but could, in theory, be generated by APC drilling. Circumstantial evidence from cores recovered during Leg 160 suggests that many such faults could have been induced by drilling. Distinction between tectonic and drilling-induced faults cannot be made on the basis on their distribution. Modeling the stress patterns applied ahead of the drill bit assembly in relation to the sediment cored is required to further understanding of the deformational processes involved in piston coring.

\section{ACKNOWLEDGMENTS}

Jan Behrmann and Chris MacLeod are acknowledged for helpful reviews and discussion. The manuscript benefited from discussion with Adrian Cramp, Yossi Mart, Eugene Pollard, Alastair Robertson, and John Woodside. We would like to thank the scientific party of Leg 159 for providing unpublished data. Post-cruise financial support to conduct this research was provided by DFG and NERC.

\section{REFERENCES}

Behrmann, J.H., Lewis, S.D., Musgrave, R.J., et al., 1992. Proc. ODP, Init. Repts., 141: College Station, TX (Ocean Drilling Program).

MacLeod, C.J., Parson, L.M., and Sager, W.W., 1994. Reorientation of cores using the Formation MicroScanner and Borehole Televiewer: application to structural and paleomagnetic studies with the Ocean Drilling Program. In Hawkins, J., Parson, L., Allan, J., et al., Proc. ODP, Sci. Results, 135: College Station, TX (Ocean Drilling Program), 301-311.

Mascle, J., Lohmann, G.P., Clift, P.D., et al., in press. Proc. ODP, Init. Repts., 159: College Station, TX (Ocean Drilling Program).

Mascle, A., Moore, J.C., et al., 1988. Proc. ODP, Init. Repts., 110: College Station, TX (Ocean Drilling Program).

Nierenberg, W.A., and Peterson, M.N.A. (Eds.), 1984. Design and operation of an Advanced Piston Corer. IPOD/DSDP Tech. Rept., 21.

Parson, L., Hawkins, J., Allan, J., et al., 1992. Proc. ODP, Init. Repts., 135: College Station, TX (Ocean Drilling Program).

Paterson, M.S., 1978. Experimental Rock Deformation-The Brittle Field: New York (Springer-Verlag).

Taira, A., Hill, L., Firth, J.V., et al., 199I. Proc. ODP, Init. Repts., I31: College Station, TX (Ocean Drilling Program).

Ms 160IR-116 